\title{
Formation of the portfolio of high-rise construction projects on the basis of optimization of «risk-return» rate
}

\author{
Svetlana Uvarova ${ }^{1, *}$, Olga Kutsygina $^{1}$, Elena Smorodina $^{1}$, Khuta Gumba $^{2}$ \\ ${ }^{1}$ Voronezh State Technical University, Moscow Avenue, 14, Voronezh, 394026, Russia \\ ${ }^{2}$ Abkhazian State University, Universitetskaya Avenue, 1, Sukhum, 384904, Abkhazia
}

\begin{abstract}
The effectiveness and sustainability of an enterprise are based on the effectiveness and sustainability of its portfolio of projects. When creating a production program for a construction company based on a portfolio of projects and related to the planning and implementation of initiated organizational and economic changes, the problem of finding the optimal "risk-return" ratio of the program (portfolio of projects) is solved. The article proposes and approves the methodology of forming a portfolio of enterprise projects on the basis of the correspondence principle. Optimization of the portfolio of projects on the criterion of "risk-return" also contributes to the company's sustainability.
\end{abstract}

\section{Introduction}

When managing production and economic activities of the enterprise, it is necessary to respect the principle of conformity, which states that it is necessary that for sustainable development the system needs to ensure that the goals are consistent with the available resources, and that with efficiency - the costs incurred [1]. The conformity principle is realized in the management by introducing the proposed methodology for the formation of the portfolio of high-rise construction projects on the basis of optimizing the "risk-return" ratio, and is assessed by determining the efficiency of high-rise construction companies. Compliance with this principle at the enterprise management level is correlated with other levels of the management hierarchy through the fractality of management systems at all levels. That means, that the proposed methodology can be applied when planning and implementing a portfolio of projects of changes at the level of state or sectoral management, taking into account the modification of methods for calculating costs, effect and risk.

\section{Materials and Methods}

Treating the production program of the enterprise as a portfolio of projects it realizes, we consider it expedient to apply elements of the methodology of project and portfolio management.

\footnotetext{
* Corresponding author: uvarova_s.s@mail.ru
} 
Formation of the portfolio of projects is usually done taking into account diversification, by which we understand not only the expansion of the scope of the firm's activity and the development of new segments of the market of contract works in construction [2], but also the typology of activities for a number of characteristics. In portfolio management, portfolio diversification is treated as one of the methods to reduce the risk of a portfolio by placing financial assets in more than one type of asset whose prices or yields are weakly correlated [2]. Carrying out the typology of the elements of the enterprise's portfolio of projects on various attributes, corresponding to the terminology of the portfolio management, the portfolio of projects is diversified.

Portfolio management theory distinguishes several basic approaches to solve the optimization problem (Table 1).

Table 1. Possible approaches to optimize the "risk-return" relationship in the formation of a portfolio (compiled on the basis of [3])

\begin{tabular}{|l|l|c|}
\hline \multicolumn{1}{|c|}{ Approach } & \multicolumn{1}{|c|}{ Substantiation of the essence of the approach } & $\begin{array}{c}\text { Formalization } \\
\text { of the criterion }\end{array}$ \\
\hline $\begin{array}{l}\text { «Maximum } \\
\text { revenue» }\end{array}$ & $\begin{array}{l}\text { select the portfolio that provides the greatest result } \\
\text { (income, discounted income, profit) while providing an } \\
\text { acceptable level of risk for the investor }\end{array}$ & $\begin{array}{c}D \rightarrow \max \\
r \leq r_{p r}\end{array}$ \\
\hline $\begin{array}{l}\text { «Optimum } \\
\text { probability» }\end{array}$ & $\begin{array}{l}\text { Select a portfolio that provides an acceptable income } \\
\text { for the investor, taking into account the probability }\end{array}$ & $M(D) \rightarrow \max$ \\
\hline $\begin{array}{l}\text { «Optimum } \\
\text { variability» }\end{array}$ & $\begin{array}{l}\text { Select a portfolio that has the least variability of income } \\
\text { when the conditions change, that is, with a minimum } \\
\text { variation }\end{array}$ & $C V(D) \rightarrow$ min \\
\hline «Minimal risks» & $\begin{array}{l}\text { Select a portfolio that ensures minimization of risk } \\
\text { while keeping income at a given level }\end{array}$ & $\begin{array}{l}D=D_{p r} \\
r \rightarrow \min \end{array}$ \\
\hline
\end{tabular}

The of investment portfolios is based on the method of "medium-variance analysis" proposed by G. Markowitz. The essence of the average variance analysis is the formation of the portfolio, based on the requirements of the investor on the basis of the minimum risk approach or maximum profitability [4]. This approach allows you to take into account the level of risk at all stages of the typology of the enterprise portfolio.

In general, similar to the portfolio approach, the methodology for forming a portfolio of projects is of a probabilistic nature.

Then we denote the set of states of the market environment as $\Omega$. Vector $D=(D 1$, $\mathrm{D} 2, \ldots \mathrm{Dm})$ represents a set of alternative elements of the portfolio for each feature of the typology $\mathrm{T}=(\mathrm{T} 1, \ldots \mathrm{Tn})$. That means, that the entire portfolio of projects of the enterprise (as well as the investor's investments) can be represented in the form of a matrix of dimension $\mathrm{m} \times \mathrm{n}$, where the columns show signs of typology, and the lines - available alternatives. The methodology calculates one attribute of the typology.

The effect indicators corresponding to each alternative element of the project portfolio (revenue, revenue or profit, depending on the alternative) are a vector $\mathrm{E}=(\mathrm{E} 1, \mathrm{E} 2, \ldots \mathrm{Em})$ of random values, which are defined in the set $\Omega$, and performance indicators form a vector $\varphi$ of the same dimension and characteristics [5].

The production program is a portfolio of projects whose permissible aggregate is defined as $\mathrm{S}$. Then the enterprise forms such m-dimensional vector of the portfolio $\mathrm{P}$, which characterizes the distribution of the resource $\mathrm{Z}$, representing the volume of the production program, into $m$ types of activities (or CIW, or projects) according to the shares $d_{i j}$.

The parts are determined in the case of the optimal probability approach according to the competitive mechanism, in other cases - according to the Markowitz model.

It should be noticed, that in last case, it is necessary to observe the condition of nonnegativity of parts (in contrast to the task of classical portfolio management). It is also 
necessary to calculate the covariance matrix of the efficiency of alternative elements of the production program $C=\left\{C_{j k}\right\}_{j, k=1}^{m}$, which is determined positively and has inverse matrix.

It should also be noted that operating the average values in this case is mathematically incorrect, therefore, in calculations for the account of the stochastic nature of the data, it is necessary to operate with probability values, that is, mathematical expectations of the values [6].

Proceeding from the foregoing, we proposed a methodology for the formation of a portfolio of enterprise projects on the basis of optimizing the "risk-return" ratio (Figure 1).

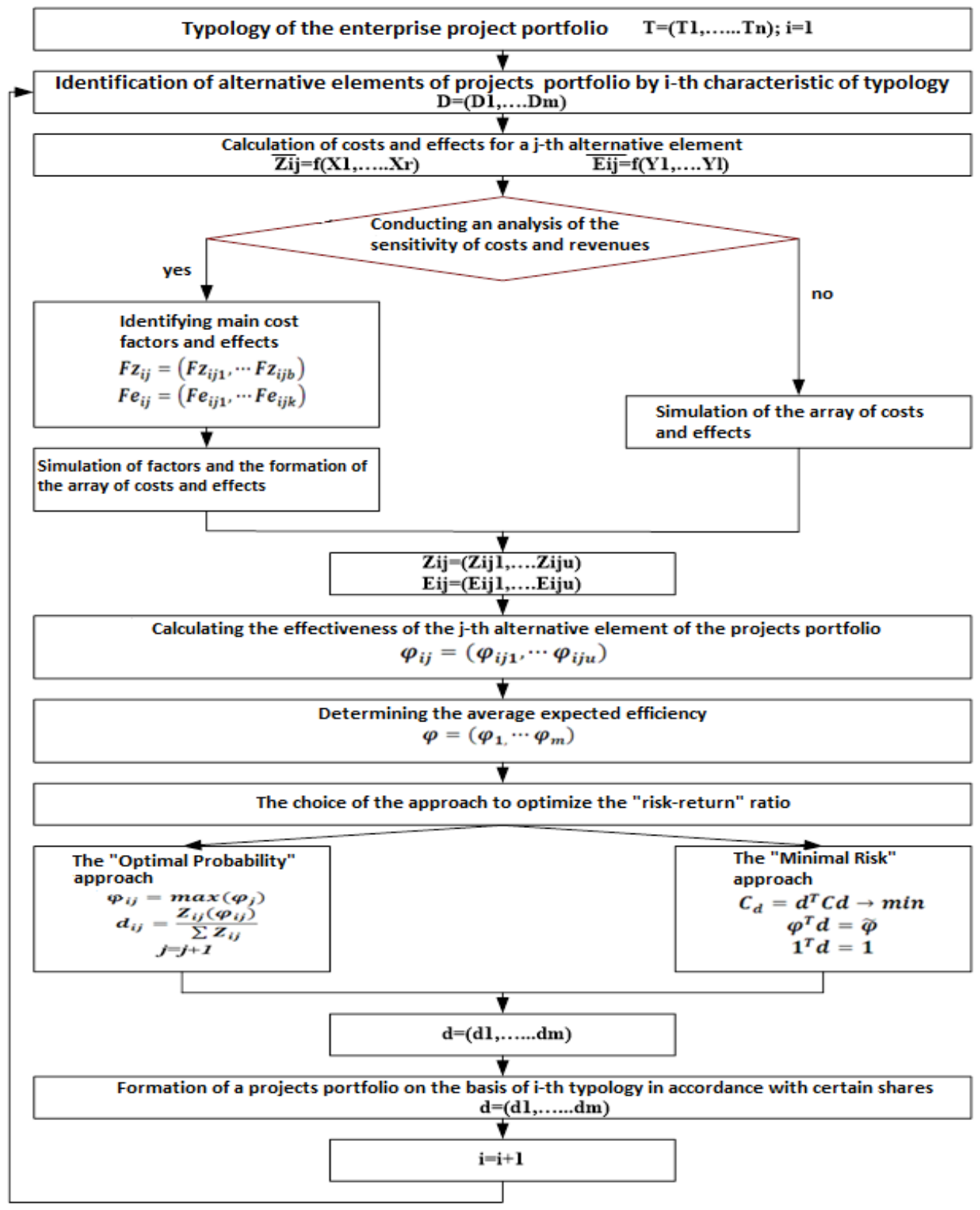

Fig. 1. Block diagram of the algorithm of the methodology for forming the portfolio of projects of the enterprise on the basis of optimization of the ratio "risk-return". 


\section{Results}

We will site the algorithm for the formation of a portfolio of projects according to the proposed methodology using the example of the "Souzspetsstroy" enterprise.

The enterprise performs general construction and special construction works, performs the functions of general contractor and subcontractor, carries out work on state and non-state orders. The typology of projects portfolio is shown in Table 2 (is not exhaustive).

Table 2. The typology of projects portfolio of "Souzspetsstroy" enterprise

\begin{tabular}{|l|l|}
\hline \multicolumn{1}{|c|}{$\begin{array}{c}\text { Characteristics of } \\
\text { typology }\end{array}$} & \multicolumn{1}{|c|}{ Alternative elements } \\
\hline $\begin{array}{l}\text { Form of ownership of the } \\
\text { customer }\end{array}$ & $\begin{array}{l}\text { Participation in the projects of a state customer } \\
\text { Participation in the projects of a non-state customer } \\
\text { Participation in PPP projects }\end{array}$ \\
\hline Performed functions & $\begin{array}{l}\text { Gencontracting } \\
\text { Subcontracting }\end{array}$ \\
\hline $\begin{array}{l}\text { Phases of the life-cycle of } \\
\text { the project }\end{array}$ & $\begin{array}{l}\text { Laboratory quality research } \\
\text { Construction and installation work }\end{array}$ \\
\hline $\begin{array}{l}\text { Types of civil and } \\
\text { erection works according } \\
\text { to Rosstat typology }\end{array}$ & $\begin{array}{l}\text { 45.1 Preparation of the construction site } \\
\text { 45.2 Construction of buildings and structures } \\
\text { 45.4. Finishing work } \\
\text { 45.5 Renting of construction machinery and equipment }\end{array}$ \\
\hline $\begin{array}{l}\text { Types of construction } \\
\text { works }\end{array}$ & $\begin{array}{l}45.21 .1 \text { Executing of common building works for erection of } \\
\text { buildings } \\
45.21 .2 \text { Executing of common building works for erection of bridges, } \\
\text { elevated highways, tunnels and underground roads } \\
45.21 .7 \text { Mounting of buildings and structures }\end{array}$ \\
\hline
\end{tabular}

As part of the calculation of the proposed methodology, the classification can be aggregated depending on the set of characteristics.

The initial data for the calculation based on the typology "Types of general construction works" are given in Table 3. It should be noticed, that calculations are made, depending on three alternatives $(\mathrm{m}=3)$ as part of one of typological characteristics. Then the profit values for each alternative form vectors E1, E2, E3, the cost values are vectors Z1, Z2, Z3, and the efficiency values are vectors $\varphi$ of the same dimensions and characteristics.

Table 3. Cost and proceeds from the construction of residential high-rise buildings, highways and mounting the prefabricated structures, planned on the basis of actual data (thousand rubles accrued) and the primary design characteristics of data sets

\begin{tabular}{|c|c|c|c|c|c|c|c|c|}
\hline \multirow[t]{2}{*}{ Index } & \multicolumn{4}{|c|}{ Quarter } & \multirow[t]{2}{*}{ Average } & \multirow[t]{2}{*}{ Dispersion } & \multirow{2}{*}{\begin{tabular}{l|} 
Standard \\
deviation
\end{tabular}} & \multirow{2}{*}{$\begin{array}{c}\text { The } \\
\text { coefficient } \\
\text { of variation }\end{array}$} \\
\hline & 1 & 2 & 3 & 4 & & & & \\
\hline \multicolumn{9}{|c|}{ Road construction } \\
\hline $\begin{array}{l}\text { quarterly } \\
\text { revenue }\end{array}$ & 10413 & 22987 & 34446 & 47399 & 11849,75 & 1319544,92 & 1148,71 & 0,10 \\
\hline $\begin{array}{l}\text { cost per } \\
\text { quarter }\end{array}$ & 9854 & 20619 & 30383 & 41357 & 10339,25 & 383516,92 & 619,29 & 0,06 \\
\hline efficiency & 1,06 & 1,11 & 1,13 & 1,15 & 1,14 & 0,01 & 0,06 & 0,05 \\
\hline \multicolumn{9}{|c|}{ Civil high-rise construction } \\
\hline $\begin{array}{l}\text { quarterly } \\
\text { revenue }\end{array}$ & 36582 & 66443 & 127494 & 180152 & 45038,00 & 205441944,67 & 14333,25 & 0,32 \\
\hline $\begin{array}{l}\text { cost per } \\
\text { quarter }\end{array}$ & 29415 & 62026 & 119692 & 164998 & 41249,50 & 166878579,00 & 12918,15 & 0,31 \\
\hline efficiency & 1,24 & 1,07 & 1,07 & 1,09 & 1,10 & 0,02 & 0,14 & 0,13 \\
\hline
\end{tabular}




\begin{tabular}{|l|r|r|r|r|r|r|r|r|}
\hline $\begin{array}{l}\text { quarterly } \\
\text { revenue }\end{array}$ & 17377 & 32158 & 53719 & 71572 & 17377 & 7802208,00 & 2793,24 & 0,16 \\
\hline $\begin{array}{l}\text { cost per } \\
\text { quarter }\end{array}$ & 17676 & 31476 & 51435 & 64733 & 17676 & 10163046,25 & 3187,95 & 0,20 \\
\hline efficiency & 0,98 & 1,07 & 1,08 & 1,34 & 1,12 & 0,02 & 0,16 & 0,14 \\
\hline
\end{tabular}

In order to take risks into account in assessing the effectiveness of each type of work, we performed simulation of costs and effects, then we calculated the arrays of values of the mathematical expectation of efficiency. In the presence of cost and effect dependencies on external and internal factors, analogous calculations can be made by sensitivity analysis, which is reflected in collective monograph. Results of simulation modeling are partially given in Table 4.

Table 4. Results of simulation modeling of the arrays of costs and effects, calculation of the efficiency

\begin{tabular}{|c|c|c|c|}
\hline & $\begin{array}{c}\text { Costs for the implementation of } \\
\text { road construction, thousand } \\
\text { rubles }\end{array}$ & $\begin{array}{c}\text { Proceeds from the } \\
\text { implementation of road } \\
\text { construction, thousand rubles }\end{array}$ & $\begin{array}{c}\text { Efficiency of road } \\
\text { construction }\end{array}$ \\
\hline 1 & 10792,05 & 8409,611 & 0,67073 \\
\hline 2 & 11002,73 & 13268,68 & 1,262933 \\
\hline 3 & 9857,095 & 12583,42 & 1,179416 \\
\hline 4 & 11328,16 & 11974,03 & 1,105146 \\
\hline 5 & 10740,19 & 13320,62 & $\ldots$ \\
\hline $\begin{array}{c}\text { etc. 500 } \\
\text { immitations }\end{array}$ & $\ldots$ & $\ldots$ & $\ldots 2692$ \\
\hline
\end{tabular}

The affiliation of the obtained data sets to the normal distribution of the quantities is confirmed by the calculation of the asymmetry error and kurtosis error criteria [7].

Histograms of efficiency are presented in Figures $2-4$.

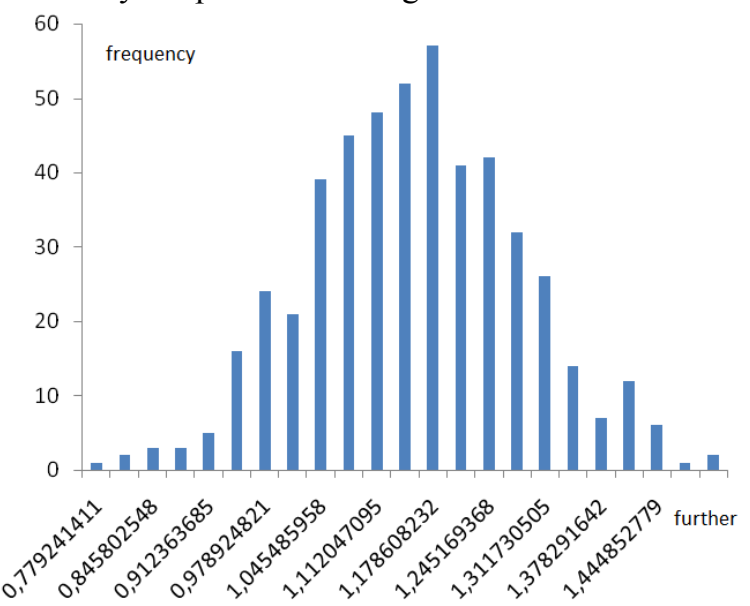

Fig. 2. Histogram of efficiency of road construction 


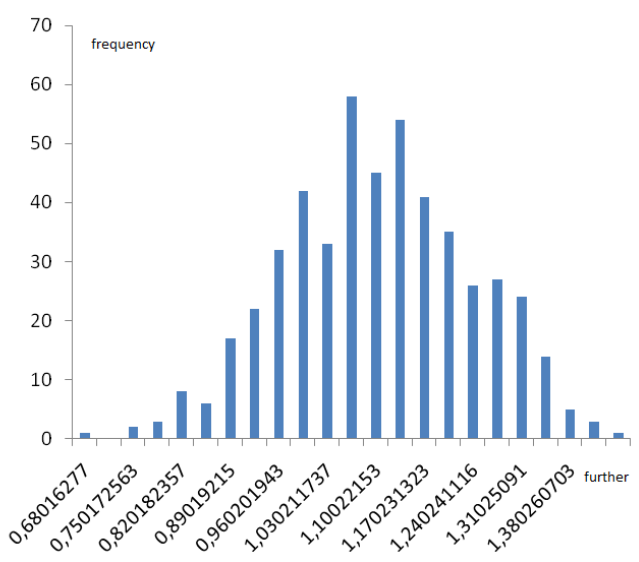

Fig. 3. Histogram of efficiency of civil high-rise construction

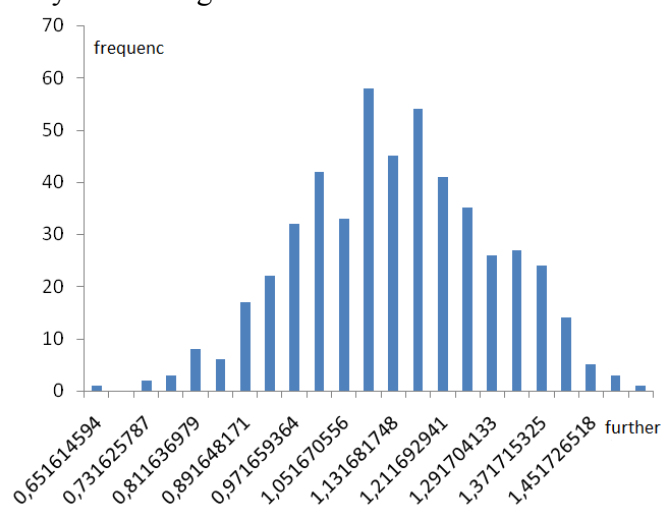

Fig. 4. Histogram of efficiency of mounting of prefabricated structures

The results of calculating the effectiveness and risk of the elements of the project portfolio are summarized in Table 5.

Table 5. Values of the effectiveness and risk of elements of the project portfolio

\begin{tabular}{|l|c|c|}
\hline Alternative elements of projects portfolio & $\begin{array}{c}\text { Average effectiveness } \\
\text { expected }\end{array}$ & $\begin{array}{c}\text { Risk (standard } \\
\text { deviation) }\end{array}$ \\
\hline Road construction & 1,14 & 0,13 \\
\hline Civil high-rise construction & 1,10 & 0,14 \\
\hline Mounting of prefabricated structures & 1,12 & 0,15 \\
\hline
\end{tabular}

According to the competitive mechanism of resource allocation, construction works on construction of highways will be included as elements of the project portfolio; in case of the presence of resources - work on the mounting of structures from prefabricated structures, in the case of the availability of resources - construction works for the construction of high-rise civil buildings. We will compile a portfolio of projects on the criterion of risk minimization. For this, it is necessary to calculate the covariance matrix of efficiencies (Table 6).

Solving the optimization problem in the SPSS program, we obtained the following results. Formation of the production program based on the ratio of 30\% - performing general construction works on the construction of highways, $70 \%$ - performing civil works for the construction of high-rise civil buildings will ensure the efficiency of the activity at the level of 1.11 at a risk level of 0.016 (the share of elements of the production program amounted to 0.27 and 0,72 respectively). 
Table 6. Covariance matrix of efficiencies

\begin{tabular}{|l|c|c|c|}
\hline & $\begin{array}{c}\text { Efficiency of high- } \\
\text { rise civil } \\
\text { construction }\end{array}$ & $\begin{array}{c}\text { Efficiency of road } \\
\text { construction }\end{array}$ & $\begin{array}{c}\text { Efficiency of mounting of } \\
\text { prefabricated structures }\end{array}$ \\
\hline $\begin{array}{l}\text { Efficiency of high-rise civil } \\
\text { construction }\end{array}$ & 0,018666 & 0,014628 & 0,021333 \\
\hline $\begin{array}{l}\text { Efficiency of road } \\
\text { construction }\end{array}$ & 0,014628 & 0,016125 & 0,016718 \\
\hline $\begin{array}{l}\text { Efficiency of mounting of } \\
\text { prefabricated structures }\end{array}$ & 0,021333 & 0,016718 & 0,02438 \\
\hline
\end{tabular}

Calculation of the model according to the "maximum effect" approach gives the following result: the efficiency of the enterprise at the level of 1.14 is provided by performing works on the construction of highways, the risk at the same time will be 0.018 . The Soyuzspetsstroy management entities have chosen to implement the project portfolio option corresponding to the "minimum risk" approach.

\section{Discussions}

Implementation of the proposed methodology in the practice of construction companies, in our opinion, contributes to the competitiveness of enterprises, effective structural changes in the industry, which becomes particularly relevant in the context of Russia's membership in the WTO. As part of the proof of the truth of the correspondence principle, we calculated the coefficient of pair correlation of indicators and performance factors of enterprises of the construction industry of Russian Federation for 2009-2016. The results of the correlation analysis are given in Table 7.

Table 7. Results of the correlation analysis of performance enterprises of the construction industry of Russian Federation

\begin{tabular}{|c|c|c|c|c|c|c|c|c|c|c|c|}
\hline & 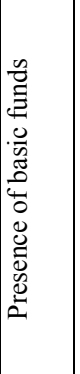 & 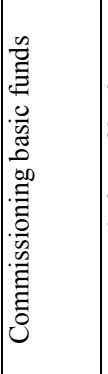 & 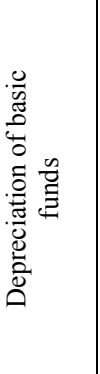 & 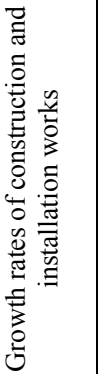 & 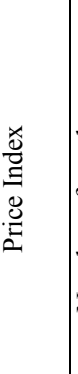 & 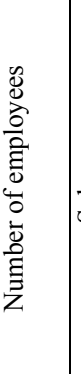 & $\frac{\vec{\Xi}}{\sqrt{\pi}}$ & 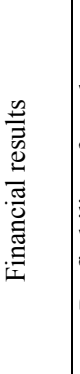 & 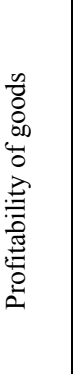 & 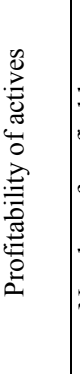 & 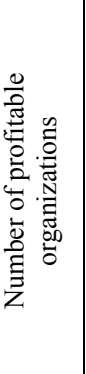 \\
\hline $\begin{array}{l}\text { Availability of fixed assets, } \\
\text { billion rubles }\end{array}$ & 1,00 & $-0,77$ & 0,73 & $-0,82$ & $-0,82$ & $-0,71$ & 0,83 & $-0,95$ & $-0,95$ & $-0,94$ & $-0,98$ \\
\hline $\begin{array}{l}\text { Commissioning of fixed assets, } \\
\%\end{array}$ & $-0,77$ & 1,00 & $-0,12$ & 0,92 & 0,86 & 0,42 & $-0,55$ & 0,55 & 0,54 & 0,73 & 0,67 \\
\hline $\begin{array}{l}\text { Degree of depreciation of fixed } \\
\text { assets, } \%\end{array}$ & 0,73 & $-0,12$ & 1,00 & $-0,23$ & $-0,33$ & $-0,59$ & 0,75 & $-0,90$ & $-0,90$ & $-0,71$ & $-0,81$ \\
\hline $\begin{array}{l}\text { The index of growth rates of } \\
\text { construction and installation } \\
\text { works }\end{array}$ & $-0,80$ & 0,92 & $-0,23$ & 1,00 & 0,99 & 0,72 & $-0,40$ & 0,60 & 0,61 & 0,64 & 0,67 \\
\hline $\begin{array}{l}\text { Consolidated index of } \\
\text { construction products prices, } \%\end{array}$ & $-0,82$ & 0,86 & $-0,33$ & 0,99 & 1,00 & 0,82 & $-0,40$ & 0,66 & 0,67 & 0,63 & 0,69 \\
\hline $\begin{array}{l}\text { Average number of employees, } \\
\text { thousand people }\end{array}$ & $-0,71$ & 0,42 & $-0,59$ & 0,72 & 0,82 & 1,00 & $-0,26$ & 0,69 & 0,72 & 0,44 & 0,61 \\
\hline Average monthly salary, rubles & 0,83 & $-0,55$ & 0,75 & $-0,40$ & $-0,40$ & $-0,26$ & 1,00 & $-0,87$ & $-0,84$ & $-0,96$ & $-0,92$ \\
\hline $\begin{array}{l}\text { Balanced financial result, } \\
\text { billion rubles }\end{array}$ & $-0,95$ & 0,55 & $-0,90$ & 0,60 & 0,66 & 0,69 & $-0,87$ & 1,00 & 1,00 & 0,92 & 0,98 \\
\hline Profitability of the sold & $-0,95$ & 0,54 & $-0,90$ & 0,61 & 0,67 & 0,72 & $-0,84$ & 1,00 & 1,00 & 0,90 & 0,97 \\
\hline
\end{tabular}




\begin{tabular}{|l|r|r|r|r|r|r|r|r|r|r|r|}
\hline goods, \% & & & & & & & & & & & \\
\hline Return on assets, \% & $-0,91$ & 0,73 & $-0,71$ & 0,64 & 0,63 & 0,44 & $-0,96$ & 0,92 & 0,90 & 1,00 & 0,98 \\
\hline $\begin{array}{l}\text { Number of profitable } \\
\text { organizations, units }\end{array}$ & $-0,98$ & 0,67 & $-0,81$ & 0,67 & 0,69 & 0,61 & $-0,92$ & 0,98 & 0,97 & 0,98 & 1,00 \\
\hline $\begin{array}{l}\text { Number of unprofitable } \\
\text { organizations, units }\end{array}$ & 0,86 & $-0,95$ & 0,30 & $-0,99$ & $-0,97$ & $-0,68$ & 0,52 & $-0,67$ & $-0,68$ & $-0,74$ & $-0,75$ \\
\hline $\begin{array}{l}\text { Percentage of costs, in\% of the } \\
\text { cost of construction and } \\
\text { installation work }\end{array}$ & 0.99 & $-0,98$ & 0,80 & $-0,97$ & & & & & & & \\
\hline
\end{tabular}

The number of profitable organizations, as well as the balanced financial result of organizations' activities, are in close relationship with the profitability (efficiency) of sales, the price index of construction products [8], the cost of production, which indicates the need to maintain the optimal correspondence between costs and efficiency of the enterprise to achieve the main goal of entrepreneurial activity - maximizing profit.

\section{Conclusion}

When forming the portfolio of projects, the methods of portfolio management (meanvariance analysis), probability theory, simulation modeling, econometric methods, sensitivity analysis, methods of the theory of operations research, the theory of active systems are used according to the proposed methodology.

The implementation of the proposed methodology will yield the following results:

- decrease in the overall risk of the construction company in an unstable environment;

- acceleration of adaptation of enterprises to organizational and economic changes, initiated at macro and mezzo levels;

- implementation of organizational and economic changes at the micro level with response to the development of the system;

- provision of synchronization of investment and construction complex subsystems at the micro, meso and macro levels;

- making scientifically based decisions on the diversification of production.

Optimization by the criterion of the structure of projects by the form of ownership of investment sources will allow to increase the efficiency of work with the state and non-state customers, as well as determine the feasibility of participation in projects based on PPP. According to the proposed methodology, it is possible to determine the optimal structure of investment.

\section{References}

1. O. Belyantseva, A. Panenkov, N. Safonova, IOP Conference Series: Earth and Environmental Science, 90(1), 012167, (2017)

2. I. Pan, A. Korre, S. Durucan Computers \& Chemical Engineering, 89, pp 84-105 (2016)

3. K. Gumba, O. Belyantseva, L. Kochetova Procedia Engineering. 165. P. 1323-1327 (2016)

4. S. Dedu, F. Şerban Procedia Economics and Finance, 32, (2015)

5. Wins, R. The Mathematics of Money Management Publisher Alpina Publisher. 2013.

6. X. Han, H. Wu, Q. Yang, J. Shang International Journal of Production Economics, 182, (2016)

7. I.V. Ilin, O.Yu. Iliashenko, A.I. Levina, Proc. of the 28th IBIMA Conf. - Vision 2020, pp 768-781 (2016)

8. O. Kalinina, O. Valebnikova, Advances in Intelligent Systems and Computing, 692, pp 1315-1322 (2018) DOi - 10.1007/978-3-319-70987-1_139 